\title{
VIEWPOINT
}

\section{Pedestrianization as a Strategy for Placemaking. The case of the Wakalat Street in Amman}

\author{
Kamila Ashour, Wael Al-Shamali \\ Applied Science Private University, Jordan \\ Engineering Faculty, Architectural Department \\ arch_kam@hotmail.com | dr.wael@asu.edu.jo
}

\begin{abstract}
Borrowing western strategies for organizing public spaces in Arab countries may have negative impacts. The Greater Amman Municipality (GAM) has public spaces interventions in different parts of the city. This paper discusses the development of the Wakalat Street as a public space, which is located in the Swiefieh District in AmmanJordan. Tracing the newspapers and articles about the Wakalat Street shows that there is a debate with and against the transformation of the Wakalat Street from a street to a plaza. The actions and reactions of GAM regarding the development show also uncertainty and a pragmatic approach. Methods of research for data gathering and analysis are based on qualitative approach; literature, articles, interviews, and field observations. The paper discusses issues and conditions for making successful pedestrian places through review of literature, principles and theories, and then analyses the pedestrianization of the Wakalat Street on the local context. The Jordanian experience on pedestrianization in the case of the Wakalat Street will be discussed based on the transformation decisions in relation to theory and best practice in the field. The key findings present the importance of analyzing the expected impact of pedestrianization on the economic and social aspects. The pedestrianization of the Wakalat Street has bad impact on the character of the street as a place attracting international brands; it is no longer the street of Wakalat (brands).
\end{abstract}

Keywords: pedestrianization, public spaces, social, economic, sustainability

To cite this article:

Ashour, K., Al-Shamali, W. (2020). Pedestrianization as a Strategy for Placemaking. The Case of the Wakalat Street in Amman, The Journal of Public Space, 5(I), 263-276, DOI I0.3289I/jps.v5il.I 26I

This article has been peer reviewed and accepted for publication in The Journal of Public Space.

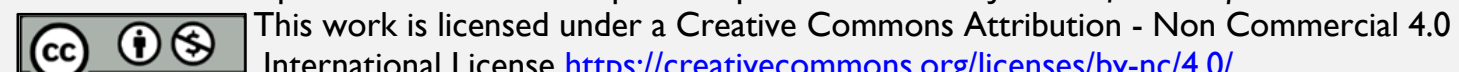

International License https://creativecommons.org/licenses/by-nc/4.0/ 


\section{Rehabilitation of the Wakalat Street}

The development objectives and strategies

The urban rehabilitation strategy concerns pedestrianization of the Salem al-Qudah Street that is known with Wakalat name respect to the existing international brands. As stated in the project document, specific issues were considered in urban analysis and rehabilitation strategies of the Wakalat Street. The analysis shows that the street was not mainly a family oriented; people target the area for specific purpose. Women are the majority users like shopping there. Outdoor fashion shows were conducted there. Shoppers are mostly of high class income. The street is known by stores for international brands (GAM, 2007). The main objective of the project is:

"Creating a "Workable Street" that encourages pedestrian life in Amman. A Street that is inclusive welcoming people from different walks of life and various socio-economic strata of society. A vibrant urban space that brings public Ammani life back to the Streets... Creating a street that wins back public life from Shopping Malls and the Strip. A potential for a workable and pleasant shopping district for Amman (a recreational promenade). A smart Shopping district that challenges the doctrine that pedestrian spaces are bad for business... This project represents a break away from the emerging gated communities in Amman... different activities such as walking, eating, listening to a band, children playing, eating, a place to see and to be seen"

(GAM, 2007)

The project aspires to create an inclusive and welcoming environment for different socioeconomic strata. The Urban design qualities and guidelines are designated to ensure a good quality image for the physical context (GAM, 2007).

"It is part of an overall strategy to create urban public spaces within Amman and has become a popular meeting place for Ammanis and city visitors. Located in Sweifieh, Wakalat Street is the beginning of a pedestrian-friendly neighbourhood" (GAM, 2008)

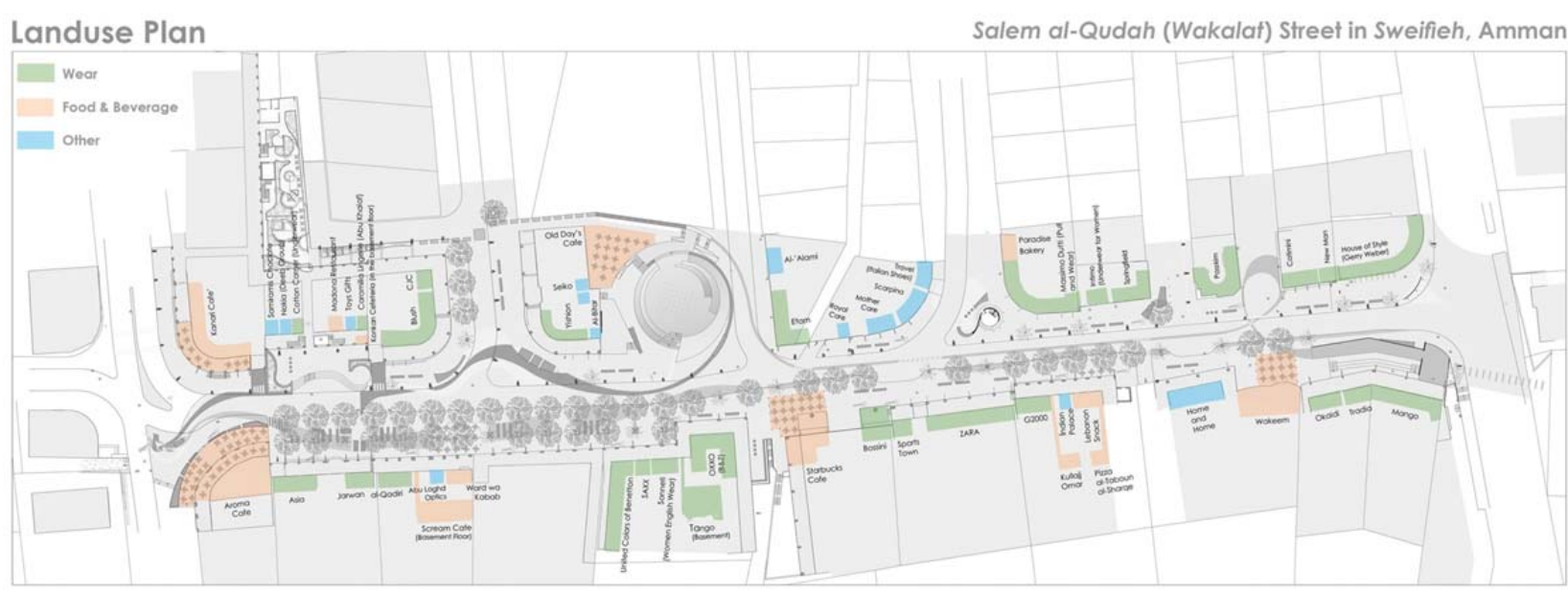

Figure I. Design Layout of Wakalat Street, GAM (2007) 


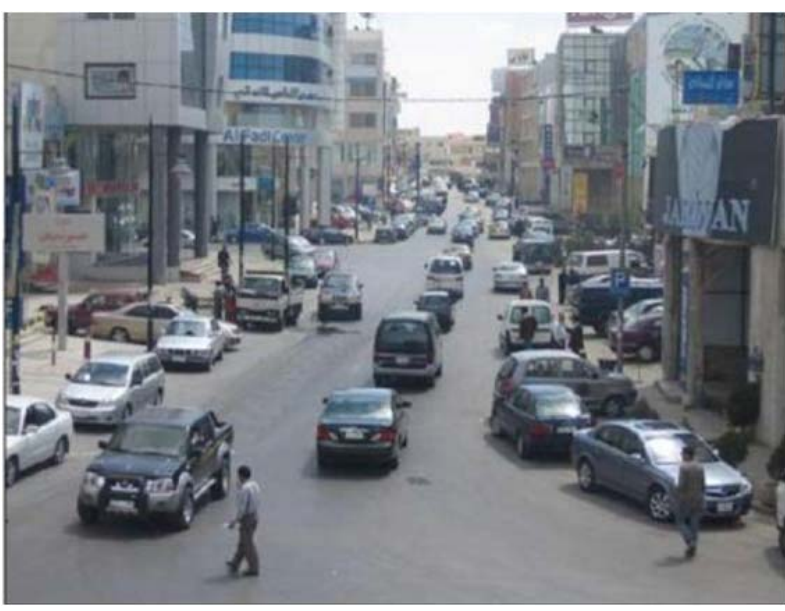

Figure 2. The Wakalat Street before pedestrianization Source: GAM (2007)

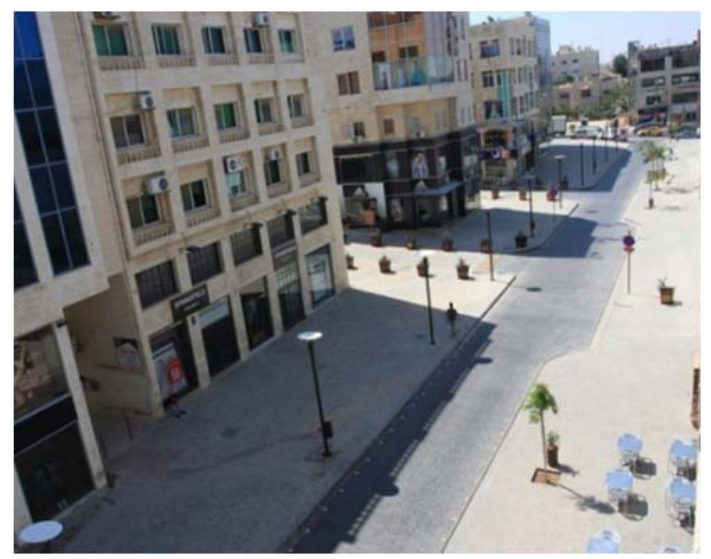

Figure 3. Reopening the Wakalat Street to vehicles, 2014 Source: Almadena-news (20/4)

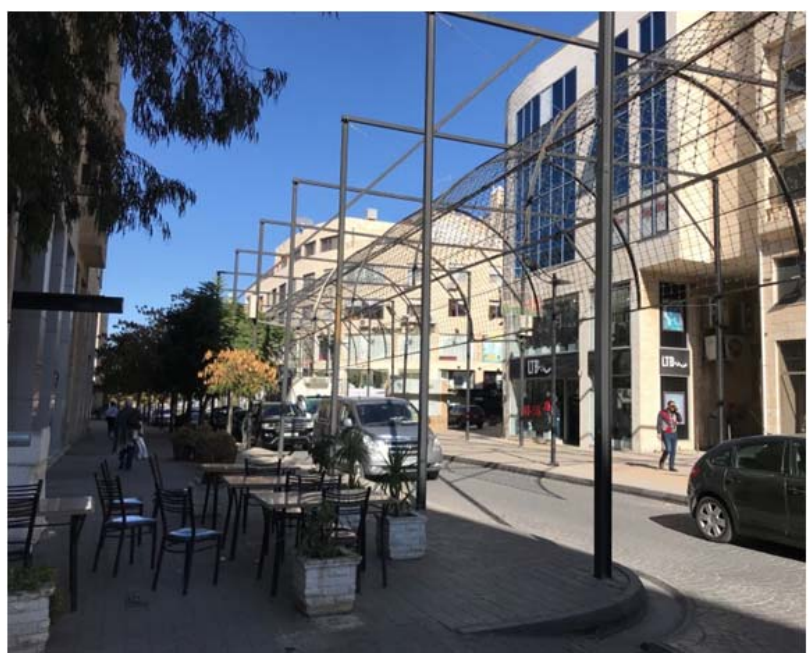

Figure 5. Wakalat in 2019 Source: by author

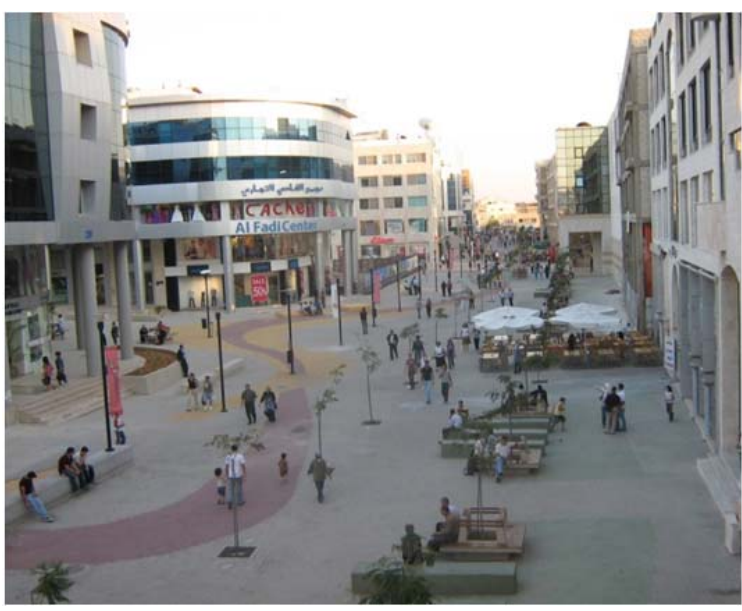

Figure 2. Pedestrianization of the Wakalat Street Source: GAM (2007)

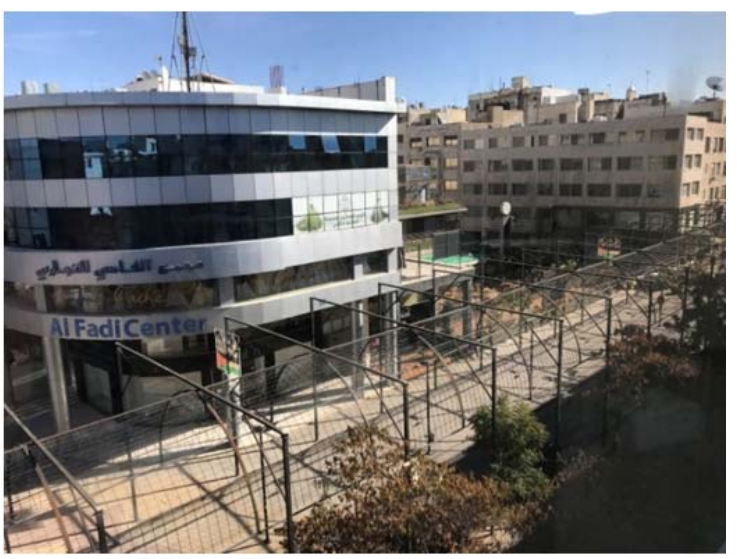

Figure 4. lighting arcade Source: by author

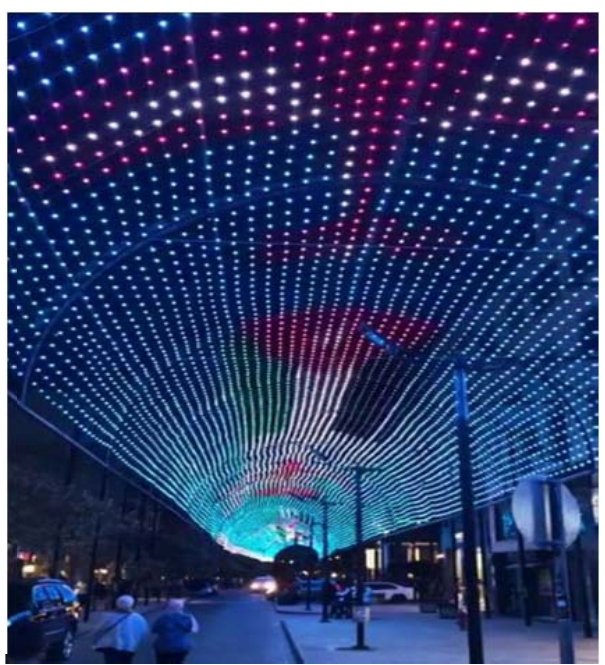

Figure 6. lighting arcade at night Source: Petra (2018) 
Exploring articles shows many feedbacks and issues that exist at the Wakalat Street as follows:

(Maani, 2007): Pedestrianization of streets for walking and shopping is a successful experience

(Alqosos, 2009): Wakalat Street is a model for public spaces in Amman (Ain-news, 2012): Wakalat Street in Sweifieh. Beauty amid contradictions (Assawsana, 2013): Wakalat Street. dim lights and immorality (Alrai, 2013): Mayor of Amman: Re-study the conditions of Wakalat Street (madenah-news, 20I3): Mayor of Amman studies the conditions of Wakalat Street to stimulate tourist traffic

(addustour, 2014): Amman Chamber of Commerce commends efforts to revitalize the Wakalat Street

(Nasr, 20I5): The Wakalat Street in decline again

(khaberni, 20l4): Wakalat Street with asphalt pavement soon

(Rum-online, 2016): Wakalat Street in Sweifieh: empty courtyards and children's playgrounds

(Ahdath, 2016): Sweifieh: financial losses for shop owners in Wakalat Street (Petra, 2018): GAM carries out decorative lighting works in Wakalat Street (Assaid, 2019): The Wakalat Street ...... has lost its luster (Salahat, 2019): Traders accuse the Municipality of Amman of premeditated "murder" of Wakalat Street in Sweifieh

\section{Literature Review}

Literature show that a full pedestrianization of streets (pedestrian malls) is not preferred. The success of pedestrian malls is limited to many factors such as the provision of adequate parking and transit systems serving dense residential areas as in the European experiences, or developing pedestrian malls where high levels of foot traffic and people seek to shop and eat, such as near offices or financial cores in large cities, university towns, and areas of tourist attraction as in the U.S. experiences. Mixed malls allow limited use of automobiles during certain hours, or transit malls that allow only public transit to pass through the streets are more encouraged. In addition, twoways roads system is better for the economy. It increases traffic flow that has good impact on the number of businesses, property value and the enhancement of pedestrian friendliness.

There is a debate about pedestrianization, its successful and failure. Both Alexander and Whyte argue that public spaces, particularly pedestrian areas, need to be located within the heart of a community or in a downtown where the highest level of pedestrian traffic exists (Alexander et al., 1977; Whyte, 1988) as cited in (Bates, 20I3). There are three types of pedestrian malls: street as plaza-pedestrian, mixed malls and transit malls. When street is closed to traffic, it functions as a plaza. The pedestrian malls compose many blocks along shopping street, modified pavement, eliminating or narrowing the pre-existing roads, increased planting and other street furniture, may include amenities such as food sources, vendors, public art. Traditional pedestrian mall is a completely closed to traffic. Mixed mall allows limited use by automobiles during certain hours. Transit mall allows only public transit to pass through (Marcus \& Francis, 1998). The pedestrian mall is a strategy to create a more friendly-pedestrian environment. The first 
built pedestrian malls as traffic-free zones were in Essen, Germany, in 1926. After the Second World War, more malls continued to develop with increasing traffic congestion in the relatively dense city centres. By 1966, there were over sixty pedestrian malls in Germany (Caves, 2005). The pedestrian free zones or malls were developed due to increased urban growth, affluence, a large number of cars, and the dense fabric with a relatively high residential population. The sixty pedestrian malls in West Germany were developed as ad hoc response to urban congestion in a number of narrow shopping streets. By 1973, about 214 malls were developed, and by 1977, there were 340 malls, and by the end of $1980 \mathrm{~s}$ there were 800 malls. The length of the malls also has increased from $7.5 \mathrm{~km}$ in 1960 to $24 \mathrm{~km}$ in 1973. Some of these malls had a variety of pedestrian zones, and other of a single pedestrian mall, and some had a series of interlocking streets, squares, and others unconnected areas. Bremen, in Germany has a central core with public buildings, the cathedral, railroad station, and it became pedestrian oriented, while traffic turned around the old city. In Hamburg, the pedestrian areas were improved through using shopping arcades of buildings blocks. As responding to the development of the suburban shopping centres in Germany in 197I, the pedestrian malls were developed as clusters of specialty shops, entertainment and restaurants to avoid the impact on shopping areas as what happened in the U.S. By the mid of 1970s, the concern was about the contribution of the pedestrian malls to upgrading the general environmental quality of an area. More focus was on integrating diverse buildings and streetscape that led to expansion of smaller malls. Recent proposals introduced "coexistence for both pedestrians and automobiles, integrated systems of circulation for urban areas that balance the need for local as well as long distance traffic" ( Rubenstein, 1992).

"Providing quality urban spaces including plazas and pedestrian malls encourages use of the city and stimulates a relaxed atmosphere for casual strolling, window shopping, and browsing". The success of pedestrian malls could be achieved with provision of convenient and economical parking and transit systems, in addition to linking spaces as in some European cities of major pedestrian areas with a variety of shops and activities, the building architectural style with the surrounding piazzas articulated a sense of scale to the urban environment. Spaces should be inviting, encourage people to interact with open spaces, outdoor cafes for gathering, relaxing and eating. The design of festival marketplaces in the United States provided a sense of place for developments. "The idea of the marketplace with its mixed uses, activities, and amenities relates back to the ancient Greek Agora where the concept for these urban spaces began to develop, and continues to serve the same human needs today" (Rubenstein, 1992).

The German experiences of pedestrian malls were imported to the U.S. where two hundred pedestrian malls were developed between 1950s and 1960s to counter the growth of suburbanization. Downtowns closed the street to traffic, but the shoppers complained of lack of parking and crimes. But in 1990s the streets opened access to traffic. Now, most of the built pedestrian malls are no longer traffic-free zone (Caves, 2005). Pedestrian malls are where the main vehicular artery is closed. Most of the American downtown pedestrian malls have been unsuccessful. Closing roads would have impact on surrounding streets, failing to accommodate large volumes of automobile traffic, and so it was unattractive for visitors. Pedestrian malls are successful when high levels of foot traffic and people seeks to shop and eat, such as near offices or 
financial core in large cities, university towns, and areas of tourist attraction. Traffic management could be through using shuttle bus to reduce the mall and downtown's parking demands, partial closures weekly or annual closures to encourage walking. The street must be both automobile and pedestrian-friendly. Walkability would be enhanced by creating pedestrian-friendly environments. This would increase open spaces and improve a sense of community (Schmidt, 2010).

A report prepared to help preparing strategies for the future of Downtown Fresno's Fulton Mall corridor, discusses the trends of the American pedestrian malls over the last 50+ years. The pedestrian malls were developed in 1960 and 1970s. The report shows that about $89 \%$ of pedestrian malls (streets open for pedestrian and closed to vehicles) failed. The II\% successful pedestrian malls are located in areas of populations under 100,000, attached to a major anchor such as a university or a major tourist location such as Las Vegas. The streets shopping have more investment, higher occupancy rate and more pedestrian traffic. About 170 other U.S. cities reopened the streets to vehicles. "The problems of pedestrian malls include a deteriorated retail mix, lack of visibility and access for retail, an uncomfortable and threatening environment, an area that attracts loiterers, disrupted neighbourhood traffic flows and a fear of crime". Several problems the pedestrian malls have: lack of convenient parking, the exposure of shoppers to bad weather, public perceptions on crime and less shopping diversity. When few people live in downtown, the malls became lifeless after work, attracting crime and loiterers, rather than large crowds. The pedestrian malls experience a general isolation, including a lack of eyes on the street for perceived safety and comfort, lack of visibility amongst landscaping and difficulties of parking and access. Thus, in most cases pedestrian malls in North America have experienced negative economic results from the original conversion. With reopening streets to vehicles, $90 \%$ of cities see significant improvements in occupancy rates, retail sales, property values, and private sector investment in the downtown area when streets are restored (Judge, 20I3). According to Karras (20l4), strategies to make downtowns vibrant are: Turn one-way streets into two-way streets, "one-way streets are great if your only goal is to channel traffic through your downtown, but they are bad for pedestrian activity and retail opportunities. Twoway streets create a more comfortable pedestrian environment and have been shown to increase property values", establish a regularly occurring public event with showcasing the downtown merchants, music, and food, create more land for development (landfill into a body of water, remove land from a floodplain, take back land from a freeway, etc), make under-utilized public land available for private sector development, consolidate regional economic development partner organizations into a single downtown location, create a permanent public market, open a downtown satellite campus of a local university, build a streetcar line connecting your downtown to an adjacent urban neighbourhood, create an awesome downtown playground to make your downtown more kid-friendly and family-friendly, create a branded downtown entertainment district, establish maximum parking standards for new downtown developments, or at least remove minimum parking requirements for new buildings, and set up a downtown bike share program (Karras, 2014 ).

The Transit-combination pedestrian malls allows for both pedestrians and some type of transit, such as light rail, bus, trolley, or taxi. The multi-modal component in these spaces have allowed for greater economic viability of the area, greater access and connections, less confusion and actually, more pedestrian traffic. By combining various 
modes of transportation, these spaces allow for greater access, connections, eyes on the street, and choice for the user. This hybrid approach allows for a pedestriandominated space, while incorporating the vital elements of access and connectivity with the rest of the urban grid. This approach requires partnership with local transit organizations, taxi companies, downtown organizations, and other stakeholders. Management of the district can often include a budget to cover maintenance, operations and repairs for the transit-pedestrian mall. Often, these are expensive endeavors (Judge, 20I3).

\section{Discussion}

Reviewing literature provides a framework for the impact of pedestrianization strategy on different aspect of life; social, economic and accessibility dimension, in addition to identification of factors contributing to the success of pedestrian malls, refer to Table I. The framework guides discussion of these aspects on the pedestrianization of the Wakalat Street in relation to the location, urban design principles, accessibility, and economic, social dimensions.

Table I. A framework for analyzing pedestrianization

\begin{tabular}{|c|c|}
\hline Impact of pedestrianization & Factors for successful pedestrian mall \\
\hline 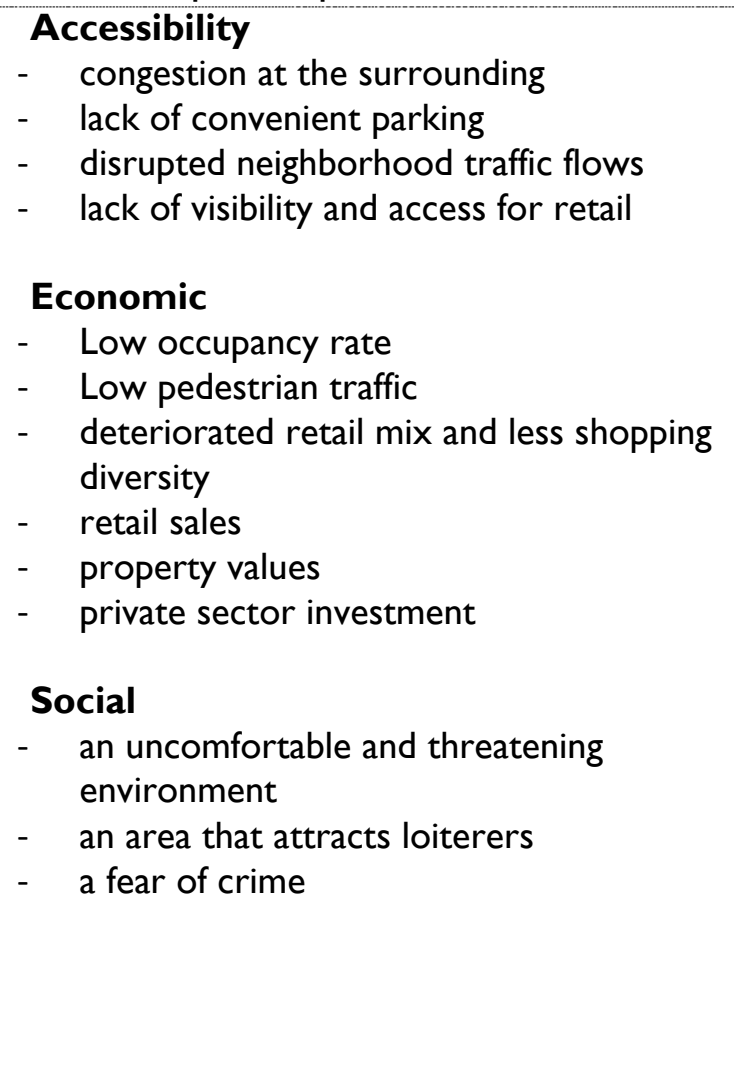 & $\begin{array}{l}\text { Location } \\
\text { - At the heart of a community or } \\
\text { downtown } \\
\text { - In dense residential areas } \\
\text { - } \quad \text { where high levels of foot traffic and } \\
\text { people seeks to shop and eat, such as } \\
\text { near offices or financial core in large cities } \\
\text { - } \quad \begin{array}{l}\text { attached to a major anchor such as a } \\
\text { university or a major tourist location }\end{array} \\
\text { Urban design } \\
\text { - linking spaces with a variety of shops and } \\
\text { activities } \\
\text { - Spaces should be inviting, encourage } \\
\text { people to interact with open spaces, } \\
\text { outdoor cafes for gathering, relaxing and } \\
\text { eating } \\
\text { provision of convenient and economical } \\
\text { parking and transit systems } \\
\text { Providing quality urban spaces } \\
\text { - Pedestrian malls were developed as } \\
\text { clusters of specialty shops, entertainment, } \\
\text { restaurants to counter the attractions of } \\
\text { the suburban malls }\end{array}$ \\
\hline
\end{tabular}


Location

The Wakalat Street is not the right location to develop a pedestrian mall. Although it lies in a mixed use center in Sweifieh that is considered one of main commercial centers in Amman, it is not a central one or a downtown, and neither located in dense residential area, refer to Figure 8 . Although there are many office spaces in the street, they are inadequate to generate enough foot traffic to support activities such as restaurants and cafes. The Wakalat Street has not been attached to a major anchor such as a university, a major tourist location or historical attractions. Therefore, pedestrian traffic is low. In addition, there are other competitive commercial corridors and centers close to Sweifieh.

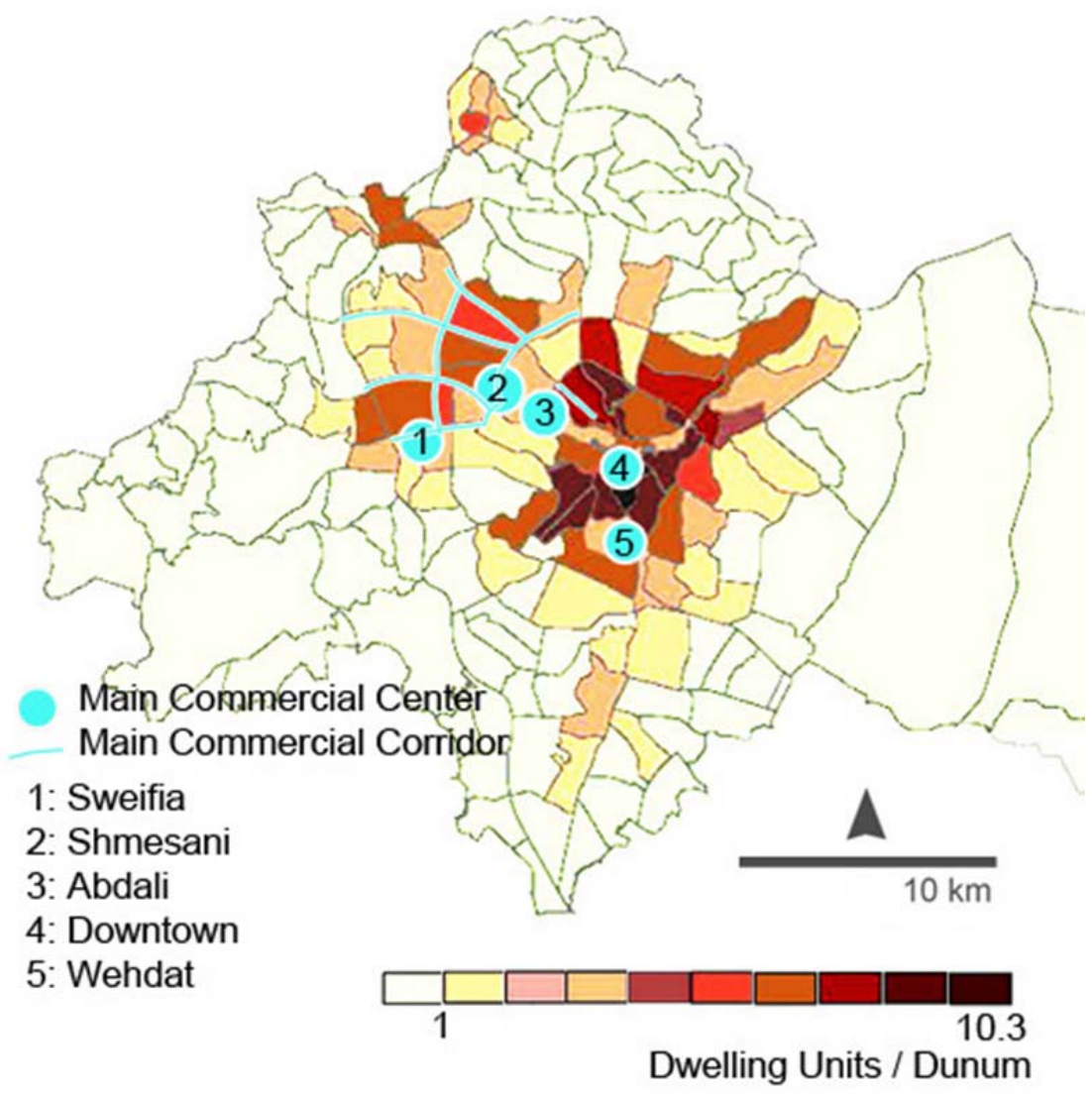

Figure 7. Neighbourhood Housing Densities and Main Centers in Amman Source: based on GAM (2008)

According to Eng. Siham al Hadidi, the development of malls in western areas of Amman specifically the City Mall in addition to many malls in Sweifieh has bad economic impact on the Wakalat Street (Hadidi, 2019). Indeed, the proximity of Galleria mall to the north of the Wakalat Street has attracted some shops, where better security and environment controls. Some brands like sunglass hut and Mango moved there. The proximity to the mall could be considered competitive to the Wakalat Street, in another way, it may become an anchor that attracts people to the area. The malls in 
Sweifiah are not of better conditions than the Wakalat Street; vacancy rate exceeds $30 \%$, and the tenants there complain of low sale rates.

\section{Urban Design}

The physical characteristics of Sweifieh may affect the foot traffic to the Wakalat Street. Analysis of the slope indicates a difference in level of over $35 \mathrm{~m}$ between the main market area and the Wakalat Street, refer to Figure $9 \& 10$. Although the distance is walkable, around $1,200 \mathrm{~m}$, the steep slope makes it unwalkable. A grid pattern of roads organizes the mixed use area of Swiefieh, the urban form of a hill and disconnected frontages due to vacant lands and residential areas have affected the place character and continuity of activity.

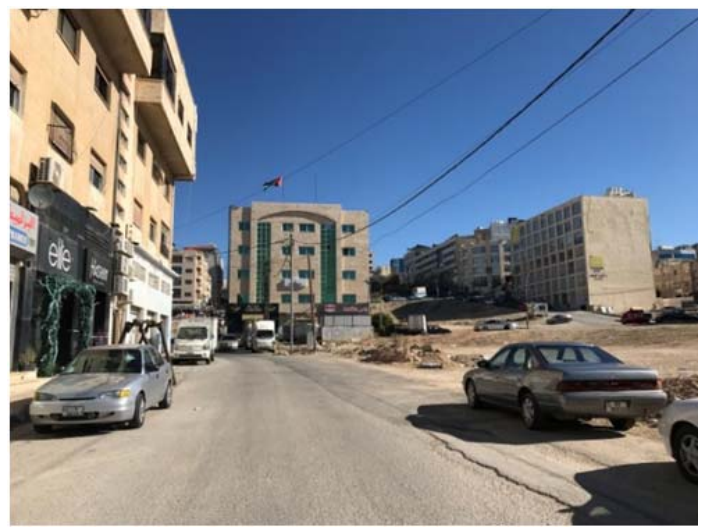

Figure .: A photo shows the discontinuation of commercial activities with the upper market Source: the author

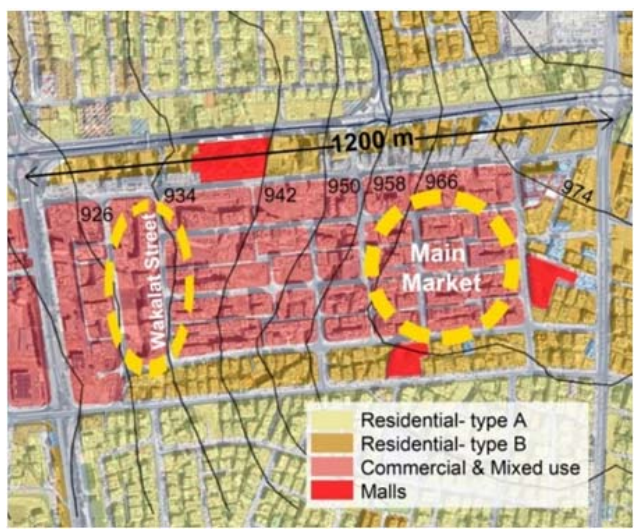

Figure 8. Sweifieh- Land use Map Source: based on maps from GAM and Google Map (2019)

As the Wakalat Street was famous with quality goods and brands, the used landscape material such as pavement of concrete tile, is below average. In a retail street, clear signage and visibility are important for the success of business. The buildings arcades, the sky lighting on metal frames, in addition to trees have reduced the stores visibility.

\section{Accessibility}

The road network of Sweifia is a grid system. The pedestrianization of the Wakalat Street disconnected the grid. At these ends car parking lots are provided. They create congestion at the entrances of the street and affect the continuity with the surrounded commercial streets, in addition to their visual impact. Most of people who are targeting the area use cars. According to the retail owners, people do not have the culture of walking, and they prefer valet parking, or parking in front of shops. GAM promised them to provide free car parking that was not achieved. Provision of convenient parking is essential to the success of the street. Most of the surrounded parking lots are for rent, free parking lots are limited. According to Eng. Siham al Hadidi, in responding to the shop owners complains, GAM decided to open partially the street of $4 \mathrm{~m}$ width (Hadidi, 2019). After reopening the street to cars, pedestrian traffic has reduced, families consider it unsafe place. As clarified by the shops owners the current situation of the area is neither a street nor a plaza. It is inconvenient to cars or pedestrians. 


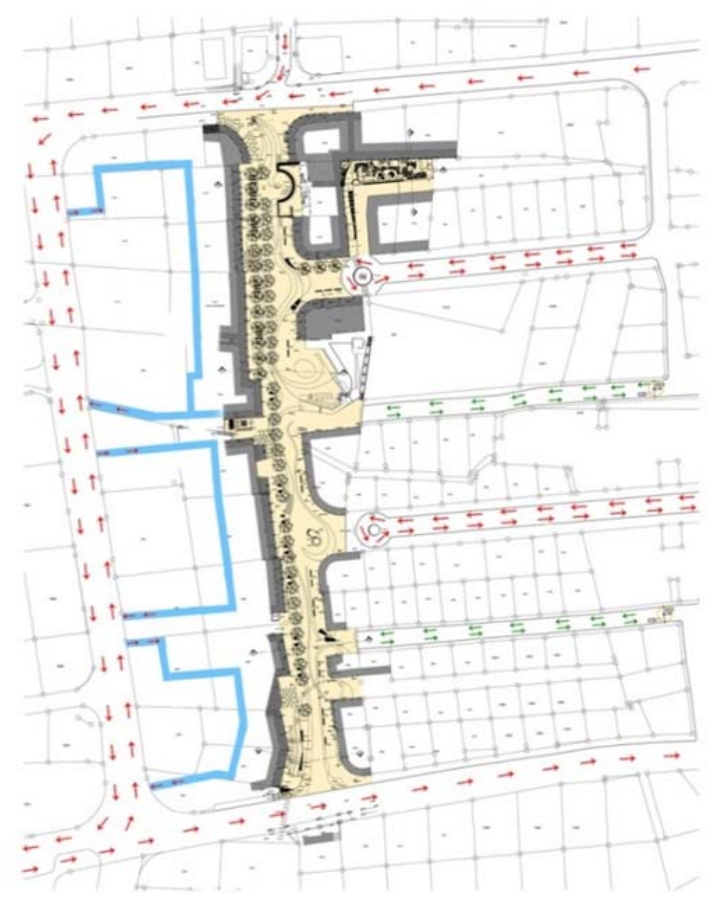

Figure 9. The circulation as per design in 2007 Source: GAM (2007)

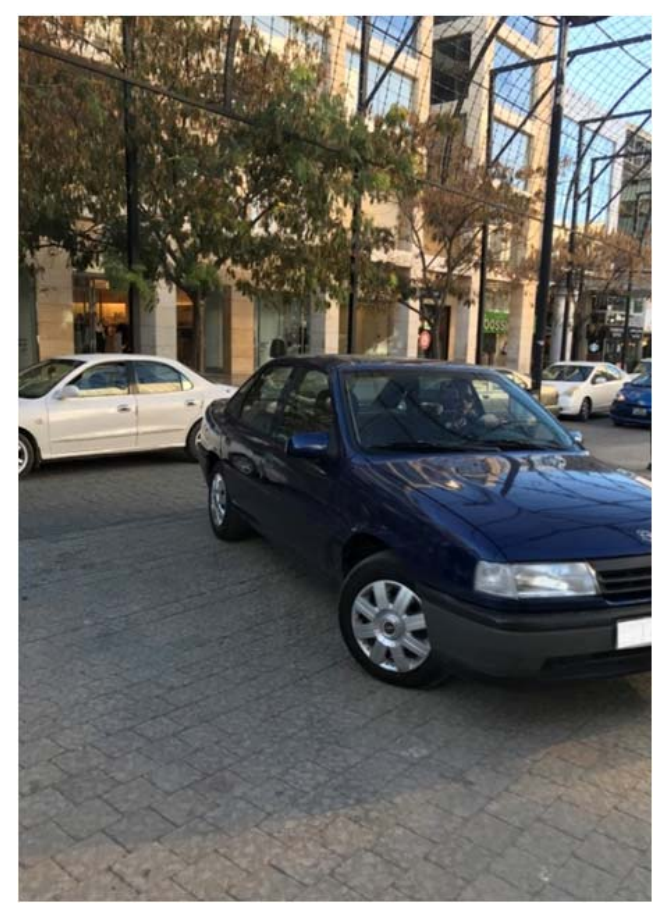

Figure 10. A person use walkways to turn, 2019 Source: the author

\section{Economic}

There could be many reasons for the economic decline of the Wakalat Street; the pedestrianization strategy, the establishment of the new mall in front of it, the general bad economic conditions in Jordan last years. The pedestrian traffic is low, and during weekend it is the highest. Based on the field survey, the occupancy rate at the Wakalat Street is around $60 \%$ to $70 \%$, and the office rent prices in the Wakalat Street is about $60 \mathrm{JD} / \mathrm{m}^{2}$. It is a competitive price in comparison with other locations in Amman, refer to Table 2. The economic conditions and investment policies in Jordan could have impact on the business development in Amman. As stated in news, in 2016, many international franchises have closed stores in Amman. They complained that taxes and operation costs are very high. The closed companies were employing around 2,000 people. The minister of the trade and industry has failed to convince them to stay in Jordan. The number of registered stores has decreased in the last two years (Alghad, 2016). Nael Kabariti, President of the Jordan Chamber of Commerce, assures that investment and tax laws have many more negative impacts than benefits, a consultation with the private sectors had to be done, and laws shall be revised (Majid, 20I4). International brands such as Mango, Gerry Weber, Pull \& Bear and Gap moved out of the Wakalat Street. However, many brands still stand in Amman's market at other locations such as the city mall and the Abdali mall. Thus, better locations attracted these brands. Interviewing the shops owners show different views on the impact of pedestrianization on the business. For some retailers, no changes on their sale; the customers keep targeting the shop. For others, the people gathering outdoor is nuisance for shoppers, and this affect sale. With respect to the food and beverage shops, the foot traffic is low, and their businesses in other locations gain more profits. 
According to many retail owners, shopping street requires a marketing strategy including defining a good tenant mix to keep attracting shoppers.

As clarified in the literature review, two-ways roads system is the best strategy to the success of commercial streets. Success of pedestrian only street requires special configurations. Asaad Al Qwasmi, a member of the Jordan Chamber of Commerce, has been involved in all issues related to the conditions of the Wakalat Street. He assures that when the Wakalat Street was open to cars in two-ways roads, it was more successful. He proposes reopening the street, providing car parking, minimizing the walkways width, providing security controls, and lowering the rent prices (Qwasmi, 2019).

Table 2: Rent prices of offices in Amman's main centers

\begin{tabular}{|l|l|}
\hline Area & Price (JD) / Sqm. \\
\hline Shmeisani & $65-80$ \\
\hline The Abdali Project & $130-150$ \\
\hline Abdali District & 80 \\
\hline Abdoun & 130 \\
\hline Swafieh & $70-90$ \\
\hline Khalda & $90-100$ \\
\hline Zahran & 70 \\
\hline
\end{tabular}

Source: http://www.century2 I jordan.com/offices-for-rent

Social

The street has become uncomfortable and threatening environment. Currently, many visitors say they are afraid to enter the Wakalat Street at all, so as not to be attacked or bothered, because many teenagers and other loiterers abuse the street so that some immoral actions are practiced by these people. In addition, the atmosphere in Wakalat Street is not friendly for visitors, especially families, in which they walk, rest or communicate, because the street itself is not friendly designed. Another factor that makes the street unattractive is the lack of fashion brands and clothing houses that normally attract people so that more time is spent there.

The solutions for these problems should be considered in administrative and urban design directions. First of all, when it comes to people's fears, the Amman municipality has to intervene by security staff all day long preventing misbehaviour people from doing bad deeds to reach the optimal level of security that definitely calms people down and makes them feel good. Secondly, the Amman Municipality must definitely reconsider its policy, in terms of the typologies of shops in Awakalat Street. It would be more successful if the Amman Municipality to find a strategy dealing with the preferred tenant mix through management and guidance. Regarding the economic situation before it was closed for the cars in 2009, it turns out that it was more successful and living place than after the closure, and the reason is that the Alwakalat Street owned many clothing stores and fashion brands that are missing now. Those were responsible for the visitors spending more time walking along the street and viewing the stores in quiet. The municipality has to work at this point again by lowering the rental costs and improving the conditions so that many of the owners of clothing stores and fashion brands come back after being forced to move out due to high rental costs. Other shopping streets 
and centres in the city were cheaper in terms of costs, so that for many owners in the Wakalat Street the conditions were not attractive enough and they had to move out. The other thing that should be seen as a major factor in developing the street and making it socially attractive as well by reviewing its urban and architectural design in order to become more prepared for visitors and families to spend more time and to reinforce the quality of the Wakalat Street as a public space. Some of the important issues in public spaces that raise the urban and architectural value such as lighting, circulation paths, green spaces and resting areas with their elements like seats, protective ceilings, garbage containers and smoking ashtrays are not studied or missing in the Wakalat Street.

Public lighting that is very important for example, in street furniture like bus stops, illuminated signs and for managing traffic, it makes the spaces in the city more attractive. In the case of the Wakalat Street it is completely the opposite. As the Figures 6 \& 7 show, it is firstly uncomfortable that visitors are permanently exposed by LED cable light that turns on and off in different colours, that cannot reassure people, especially the old of them. In addition, the entire lighting system is mounted on a huge steel frame along the street, so that the visibility of the users is not always guaranteed. Concerning the movement system, it lacks clear circulation paths by using of special tiles in different colours for example and LED lighting to better illustrate the paths.

Vital and social friendly pedestrian public spaces have good quality of physical elements that make people welcome, comfortable and create strong sense of community. The ignoring of these elements in the Wakalat Street has a great impact on the discomfort of many users because there is no opportunity to sit comfortably and enjoy the activities of the street. The fact that these physical elements (fixed benches, waste and cigarettes containers) were taken out from the Wakalat Street, this also led to its devaluation as a public gathering place that attracts people socially. As clarified in News and assured by interviewing shop owners, the provision of the public seats had become nuisance for the shoppers and the property owners. That pushed GAM to take out the public seating. Then people started to sit on ground bringing with them shisha and playing cards. By reopening the street to cars, people park at the street and sit inside their cars. From this experience, provision of public seats in a mainly retail (clothes) street cause troubles where people sit and monitor patrons while shopping. Seating in cafes and restaurants is more appropriate at a retail street. Thus, the Wakalat Street is no longer that public space where low income people would find public seats and enjoy the plaza for free.

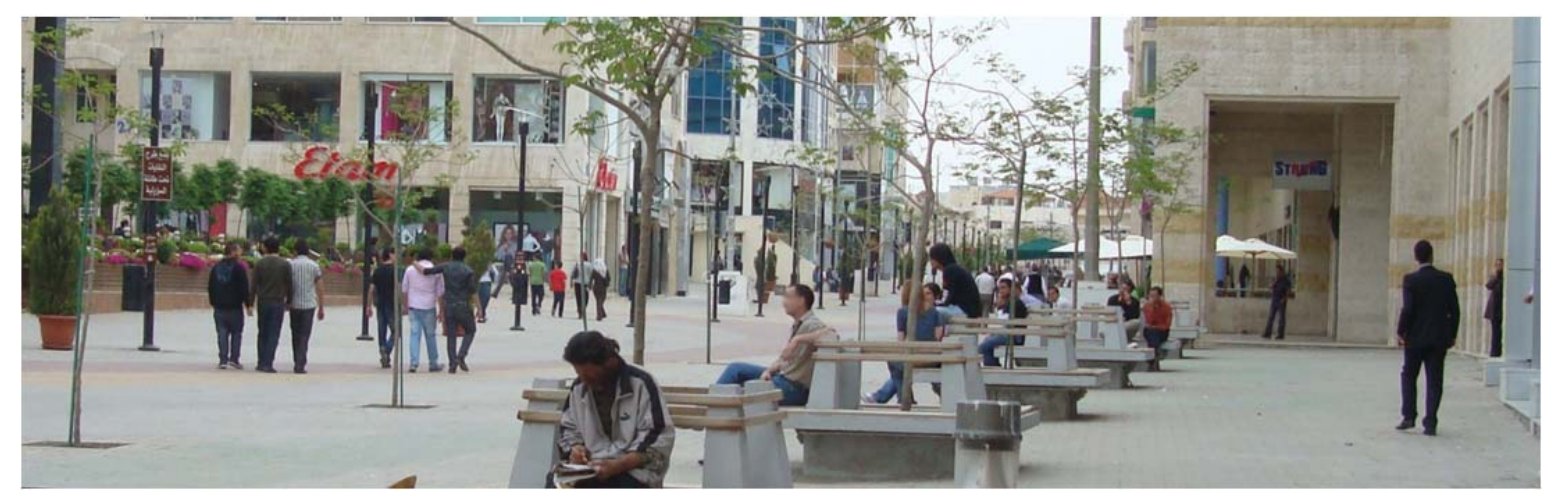

Figure II. A photo for the Wakalat Street before removing public seats and benches. Source: by author 


\section{Conclusion}

In the case of the Wakalat Street, there is a conflict between two themes; one is the creation of public spaces and the other is transformation of a shopping street into a pedestrian mall. The project aims were to create a place that is "inclusive welcoming people from different walks of life and various socio-economic strata of society. The experiences at the Wakalat Street development prove that public seats and social mixing cannot be achieved at a location where services and products are designated for a specific class of high level income. The project design objective aspired to celebrate the Wakalat Street character as a place of fashion and flowers. But the outcomes on reality show that the brands are moving out of the street. The social objectives of creating a place where women would do shopping, children would play and husbands would wait their wives in a public space have not been achieved. Decision making on which street could be a successful free car zone shall be taken with considering the type of functions and activities there. For mainly a retail street, public spaces are not appropriate. Sustainability is about balance between different aspects of life; physical, environmental, economic and social dimensions. The physical aspects of the urban design at the Wakalat Street were the main focus of the rehabilitation. While the project aimed at achieving social advantages, the project had bad social and economic impacts. Planning shall consider the economic impact on the existing business, its type and market. Analysis of economic, social and physical characteristics of the local context and culture is essential to determine the right strategy for placemaking.

\section{Bibliography}

Addustour. (2007, July 23). تخصيص شوارع للمشاة والتسوق العائلي تجربة ناجحة :الدعاني Retrieved December 30, 2019, from www.addustour.com/articles/867522-

Addustour. (2014, July 27). "تشيد بجهود إعادة إحباء شارع الوكالات "تجارة عماسنان Retrieved July 27, 2019, from addustour: https://www.addustour.com/articles/l6585I..

Ahdath. (2016, Febrauary I). خسائر مالية لاصحاب المحال في شارع الوكالات :الصويفية. Retrieved December 20, 2019, from Ahdath: http://www.ahdath24.com/article/65432

Ain-news. (2012, July 17). جمال صارخ وسط تناقضات فجة ... مارع الوكالات في الصويفية. Retrieved December 30, 2019, from Ain News: https://ainnews.net.../\#.XbyFqFXXJdh

Alexander, C., Ishikawa, S., Silverstein, M., Jacobson, M., Fiksdahl-King, I., \& Angel, S. (I977). A Pattern Language: Towns, Buildings, Construction. New York, New York: Oxford University Press.

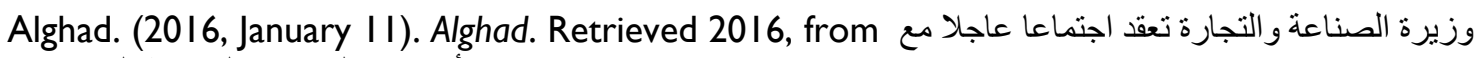
أصحاب العلامات التجارية اليوم :http://www.alghad.com/articles/9|3835-7-

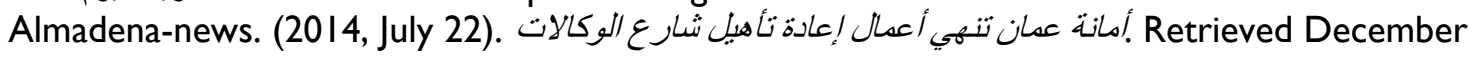
20, 2019, from Almadena News: https://www.almadenahnews.com/article/310372

Alqosos, N. (2009, October 3). شارع الوكالات كنمونج Retrieved December 20, 2019, from

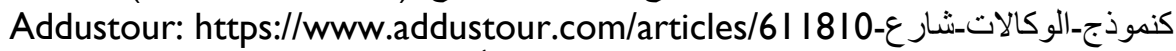

Alrai. (20I3, October 30). اعادة دراسة واقع شارع الوكالات بمين عمان. Retrieved December 20, 20I9, from Alrai: http://alrai.com/article/6I I500...

Ammon-news. (2016). Ammon news. Retrieved September 30, 2016, from الأردن لم يعد :الكباريتي

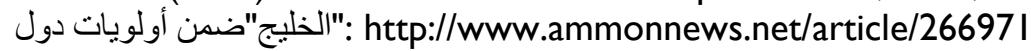

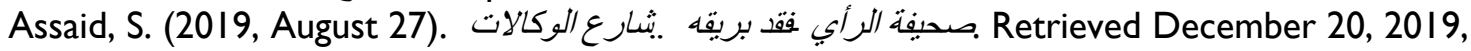
from Alrai: http://alrai.com/article// 0499330 
Assawsana. (2013, July 22). اضواء خافتة واجساد للبيع.ئارع الوكالات. Retrieved December 30, 2019 , from Assawsana: https://www.assawsana.com/portal/pages.php?newsid=149306

Bates, K. (2013, July 6). "Making Pedestrian Malls Work- Key Elements of Successful Pedestrian Malls in the US and Europe. Retrieved October 30, 2019, from Core: https://core.ac.uk/download/pdf/36687647.pdf

Caves, R. (2005). Encyclopedia of the City. USA and Canada: Routledge.

GAM. (2007). Urban Rehabilitation of the Wakalat Street. Amman.

GAM (Greater Amman Municipality) (2008): The Amman Plan Metropolitan Growth. Amman: Greater Amman Municipality.

Hadidi, E. S. (2019, December 22). Manager of Design and Studies Department at GAM. (K. Ashour, Interviewer)

Judge, C. E. (2013, October). Downtown Fresno. Retrieved May 26, 20I5, from The Experiment of American Pedestrian Malls: Trends Analysis, Necessary Indicators for Success and Recommendations for Fresno's Fulton Mall : http://www.downtownfresno.org/wpcontent/uploads/american-pedestrian-mall-experiment.pdf

Karras, J. (2014, February 5). Urban Scale. Retrieved December 10, 2014, from 12 Strategies That Will Transform Your City's Downtown: http://urbanscale.com/blog/I2-strategies-willtransform-citys-downtown/

khaberni. (2014, April 8). شارع الوكالات بإبنلت قريياً Retrieved December 20, 2019, from khaberni: https://www.khaberni.com/news....- 122164

Maani, N. (2007, July 23). تخصيص شوارع للمشاة والتسوق العائلي تجربة ناجحة :الدعاني Retrieved December 30, 2019, from www.addustour.com/articles/867522-

Madenah-news. (20I3, October 30). أربن عقّان يبرس واقع شارع الوكالات لتنشيط الحركة السياحبة. Retrieved December 20, 2019, from al madenah news: https://www.almadenahnews.com/article/255803

Majid, S. A. (20I4, January 23). Eastern Amman Investors Industrial Association. Retrieved

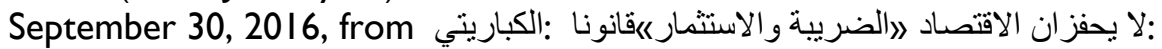
http://eaiia.org/industry-news-in-jordan/news-activities-and-developments/8047-20I4-0I-23$08-4 \mid-00$

Marcus, C. C., \& Francis, C. (1998). People Places: Design Guidelines for Urban Open Space. Canada: John Wiley \& Sons.

Nasr, R. (2015, June 17). شارع الوكالات بيقد عصب حياته من جديد Retrieved December 20, 2019, from

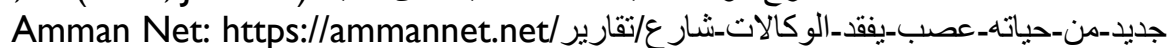

Petra. (2018, June 09). أمانة عمان تنفذ أعمال إنارة تجميلية في شارع الوكالات. Retrieved December 20, 2019, from Petra: http://www.petra.gov.jo/Include/InnerPage.jsp?ID=22863\&lang=en\&name=local_news

Qwasmi, A. A. (2019, December 30). a member of the Jordan Chamber of Commerce. (K. Ashour, Interviewer)

Rubenstein, H. M. (1992). Pedestrian malls, streetscapes, and urban spaces. New York: John Wiley \& Sons, Inc.

Rum-online. (2016, December I). باحات خاوية وملاعب للأطفال بشارع الوكالات بالصويفية Retrieved December 20, 2019, from Rum on line: http://www.rumonline.net/index.php?page=article\&id $=247903$

Salahat, S. (2019, April 29). تجار يتهون /مانة عمان بالقتل العدد لثارع الوكالات بالصويفية Retrieved December 20, 2019, from albaladnews: http://www.albaladnews.net/more-243 I30-I-

Schmidt, J. (20I0). National Association of City Transportation Officials. Retrieved April 20, 20I5, from Revisiting Pedestrian Malls : nacto.org/docs/usdg/revisiting_pedestrian_malls_scmidt.pdf

Whyte, W. (1988). City: Rediscovering the Center. New York, New York: Doubleday. 